\title{
The entanglement of the heritage paradigm: values, meanings and uses
}

\author{
Veysel Apaydin \\ Department of Culture, Communication and Media, Institute of Education, University \\ College London, London, United Kingdom.
}

To cite this article: Veysel Apaydin (2018) The entanglement of the heritage paradigm: values, meanings and uses, International Journal of Heritage Studies, 24:5, 491-507, DOI:n10.1080/13527258.2017.1390488

\begin{abstract}
This paper explores the ways in which heritage as a practice and concept has been used and diverse meanings and values ascribed to heritage by different claimants, using the medieval site of Ani in eastern Turkey as a case study. On one hand, the site marks a point of conflict between Turks and Armenians, with the heritage and the past of the site playing an important role for identity making and construction of national narratives, as well as developing what might be seen as the authorised heritage discourses for both sides. On other hand, the local community around the site has developed a different relationship to the site Ani because of their daily relationship with its landscape and built environment. This has revealed meaning and values embodied in the site that are beyond the national and political level. This paper considers to what extent the built environment in particular, can play a role in identity making and add to the political tension. It also examines how the value and meaning of a heritage site can be distinct for local communities from national political meanings and uses, and, as a consequence, can be used to resist authorised heritage discourses.
\end{abstract}

\section{Introduction}

The values and meanings embodied in cultural heritage have varied meanings for different groups. In many cases, cultural heritage, particularly tangible heritage, is often used monolithically to develop collective discourses for identity making, particularly in nation states. In contrast, the meaning and value of cultural heritage changes over time for local people who develop different scales of relationships with assets of cultural heritage or landscape through using it intensively as a resource in daily life. Additionally, cultural heritage can be crucially important for specific groups who consider specific heritage to be linked to their collective identity and how their memories are liked to place. In this paper, I examine the mediaeval site Ani, in eastern Turkey to demonstrate this. I discuss how the heritage site has been used politically to promote nationalism, for both Turks and Armenians, and from there, to form communities around nationalist narratives; how the heritage site also forms an important place in daily life for local communities whose relationship with the heritage site goes beyond this political level: by bringing out the meaning, value and sense of place at Ani.

\section{Meanings, values and uses of heritage}

Heritage is a very complex phenomenon and it is always difficult to define, particularly given its extensive study, widespread use by a wide variety of groups all with varied interpretations (see Harvey 2001). Heritage is certainly a process (Smith 2006, 300) but as part of this process, heritage is shaped, developed and even destroyed by humans. This process includes multiple aspects: the development of value and meaning over heritage and through deconstructing heritage; constructing a monument and destroying it (see Holtorf 2015); and the impacts of climate in damaging natural heritage as they are all part of this process. Heritage is also a quite 
elusive concept but has the potential to shape the personality, worldview and everyday life of individuals and groups. Although very abstract, it is an influential tool that binds people together. While there are different conceptualisations and interpretations of heritage it has inevitably politicised and a wide variety of political discourses have emerged from it. As Smith points out 'there are hegemonic discourses' about heritage which impact upon our daily life and traditionally, it as a discipline often 'promotes a certain set of Western elite cultural values as being universally applicable' $(2006,11)$. In the case of Turkey and Armenians both Armenians in diaspora and Armenians in Armenia, heritage resources is also used by elites, who control power then impose them on public. These discourses tell the public what is heritage, what is important, and what should be valued. For instance, a recent study has shown how the current local community in Hattusal interprets this cultural heritage site as part of their national identity as a process that was imposed and propagated by the Turkish state through state institutions such as history textbooks, approved by the state, and which only recognise Turkish and Islamic related material culture as a heritage and excludes e.g. minorities' heritage (Guler - Biyikli and Aslan 2013; Apaydin 2016a).

All individuals in society interpret and value parts of the material culture of the past as part of political ideology (Smith 2006, 2010, 2012); the meaning of heritage is therefore created as a result of social actions (Smith 2006; Byrne 2008). In parallel to ideological change, the definitions and uses of heritage also change over time (Ashworth, Graham, and Tunbridge 2007). Therefore, heritage is created, shaped and managed in the present; meanings are loaded onto heritage in the present to use as a resource (Ashworth, Graham, and Tunbridge 2007, 13) usually imbued with positive values (Harrison 2013, 5).

Tangible remains of the past, particularly monumental heritage are often used to present groups' links to their homelands, as well as operating as a means of storing memory for those same groups and shaping their identities. Certainly, any aspect of heritage can be said to act as symbolic of identities but the reason for focusing on monumental heritage is that it embodies the power of meaning and knowledge that are ascribed by groups and individuals more precisely and visibly compare to other forms of heritage (see Vale 2008). This is one of the reasons that during times of war monumental heritage is often the first target. This is seen in the case of Yugoslavian war where both sides targeted religious places (Bevan 2016); or where churches are converted to mosques or vice versa, as in the case of the Armenian churches in Kars, Turkey. This great interest in claiming heritage (Tunbridge and Ashworth 1995; Lowenthal 1996, 2008; Smith 2006; Ashworth, Graham, and Tunbridge 2007; Silverman 2011) is without doubt linked to asserting power and used to construct identities both as dominant populations or elites and in contestation or opposition to them (see Silverman 2011). For instance, when national identities are constructed, heritage discourse can be used to oppress other identity groups by making them 'other', and constructing place identities that provide support for these political ideologies (Ashworth and Graham 2005).

In contrast to the use of heritage for divisive politics and national narratives, heritage also has a meaning in social and daily life. At the grassroots level, value and meaning can be different (see Waterton 2005; Smith 2006; Smith and Waterton 2009) and more plural (Ashworth, Graham, and Tunbridge 2007) because the definition of heritage may vary (Smith 2006; Smith and Akagawa 2009) at the local level and be more relevant to everyday life. In her case study in the UK, the Hareshaw Linn community project in Bellingham, Northumberland, Emma Waterton (2005) emphasises how value and meaning in community level can be substantially different than those have been imposed through a top-down approach developing a Cultural Heritage Management Plan. Similarly, Hawke's (2012) study of social and daily relationship 
of locals with heritage in a case study in the North Pennines in northern England reveals the different meanings and values of heritage place at the grassroots level than the one developed by the national level power. This difference in the value and meaning of heritage phenomena can be described as concentrating on a 'sense of place' (Tunbridge and Ashworth 1995; Davis 1999; Dicks 2000; Graham, Ashworth, and Tunbridge 2000; Ashworth and Graham 2005; Smith 2006; Atkinson 2007; Crooke 2008; Schofield and Szymanski 2011; Convery, Corsane, and Davis 2012; Hawke 2012). This term is an appropriate one particularly for local people who have a different relationship with a heritage place as part of their social practices, and where the meaning of that heritage place is part of their lived experience (Ashworth and Graham 2005, 3). The definition and value of a heritage place for local people differs because they are the ones who engage with the local heritage in their everyday life and it is the local community that ascribes values to and develops memories from a heritage place.

\section{The past and current politics of heritage in Turkey}

During the final years of the Ottoman Empire nationalists took power, aiming to establish a nation state based on the concept of 'Turkishness' (Ersanl 2003). In order to succeed in this aim, every part of Turkey underwent a purification process, removing traces of any other ethnic minority group or religion, e.g. the Armenians and Greek communities (see Akcam 2004 for Armenian genocide; Akdar 2000 for population exchange). The plan of homogenising Turkey was continued in following years with an attempt to erase the history of minorities and to rewrite the history of Turkey. Following the establishment of the Republic of Turkey in 1923, the state supported research on Turkish history in order find specific historical evidence supporting the connection of modern Turks with the older civilisations of the Anatolian Peninsula in order to claim ownership rights over the land. Some of the first research started by the support of the nascent Turkish government aimed to prove ownership of Turkish territories against Armenians and Greeks, the populations living in Turkey, who were considered at aiming to annex lands from Turkey.

In the 1930s two influential congresses were organised to discuss and rewrite Turkish history (Atakuman 2008) and develop what we would now call heritage perception and policy in line with the official ideology of Turkish state, a policy based on Turkishness. The congresses and subsequent research supported by the state had quite significant results, including a major impact on the construction of the official Turkish national identity ideology (Ersanl 2003 ; Atakuman 2008), outlining and shaping the heritage policies of the state and the reception of these by the general public of Turkey. However, the use of archaeology and heritage in these putative academic endeavours was heavily focused only on Turkish history, and other cultural elements, such as minorities' history of the country were neglected.

During the post-construction period of the 1940's the politics of heritage was no different from the initial construction period, and research priorities continued having a nationalist approach to heritage and archaeology. Official perspectives on heritage and archaeology still failed to recognise the existence of heritage of any other cultural and ethnic groups in Turkey. In the history textbooks written during the construction period and in the following years, the history and heritage of Armenians and Greeks continued to be neglected and the texts focused only on the Turkish past (Guler - Biyikli and Aslan 2013).

Although the nationalist approach based on 'Turkishness' to heritage policies continued until the 1980s, the military coup in 1980 introduced a new element of 'Turkish-Islamic synthesis' (Zencirci 2014, 5) that became the official ideology of the Turkish State, and the heritage 
perspective became more explicitly Turkish and Islamic. Until the 1980s, religion and Islamic values were avoided in state institutions because Turkey was established on secular values. However, with the 1980 coup Islam became part of official ideology of the state; for instance, religion classes which were designed to teach values of Islam became compulsory (Ersanli 2003). This also impacted heavily on history books where heritage material has been

values. However, with the 1980 coup Islam became part of official ideology of the state; for instance, religion classes which were designed to teach values of Islam became compulsory (Ersanl1 2003). This also impacted heavily on history books where heritage material has been taught to students up until today (see Bilmez et al. 2017). In the following years, Turkeynatural border between Turkey and Armeni was also impacted by neoliberal policies, which led to heavy privatisation (Aydın and Taşkın 2014), which also applies to heritage. The privatisation policies continue unabated in the current day, with the Islam-oriented government that came into power in 2002 (Buğra and Savaşkan 2014, 51) beginning substantial construction projects in many parts of the country, particularly in large cities. These rampant neoliberal policies didn't necessarily change the overall Turkish ideology but they have changed the understanding of the value of the past, and its presentation through archaeology and heritage (see Apaydin 2016b). Making profits and acquiring capital have become more important than any archaeological or heritage sites (see Shoup 2006 for dam constructions in southeast Turkey).

Zencirci $(2014,2)$ points out, since 2002 when the Islam-oriented government came to power 'a new discourse of national heritage' arrived, which is dominated by constructed OttomanIslamic perspectives (see Tureli 2014,12 ) and heavily impacts heritage policies to give more importance to Ottoman and Islamic related heritage and material culture. That said, occasionally there have been some progressive developments regarding minorities' heritage as well. For instance, in 2007, Akdamar Church (the Church of the Holy Cross) dated to tenth century Armenian Kingdom, in east Turkey, restored and opened to public as a museum and added to the Tentative list of UNESCO for World Heritage Site list.2 Today, Turkey has a strict centralised administration system operating a heritage sector that is controlled and run by the Ministry of Culture, which oversees matters related to heritage, museums, excavations, surveys and all state museums and ruins. Any decisions or approvals of heritage related issues have to pass through these mechanisms (Baraldi, Shoup, and Zan 2013; Apaydin 2016b). Clearly this degree of centralisation has significant implications for the use of heritage resources by non-state approved or minority groups.

\section{Historical background of the site and current communities}

Ani is located in the east of Turkey close to the city of Kars near to the Armenian border (Figures 1 and 2). The site contains considerable amounts of Byzantine, Seljuk, Islamic, Arabic, Persian and Georgian archaeological remains and is especially famous for its Mediaeval Armenian architectural heritage, particularly for its churches (see Cowe 2001; Figures 3 and 4). The site was first significantly developed during the tenth century AD when it was the capital of the Armenian Kingdom and during the nineteenth and twentieth centuries the wider Ani province was quite multicultural, with groups including Armenians, Yezidis, Assyrians, and Malakans (Akçayöz et al. 2007). Today the population of the region is mostly a combination of Turkish and Kurdish people. However, the multicultural past can still be seen all around the province of Ani in the material culture around Ani and in the city of Kars (Figures 5 and 6). 


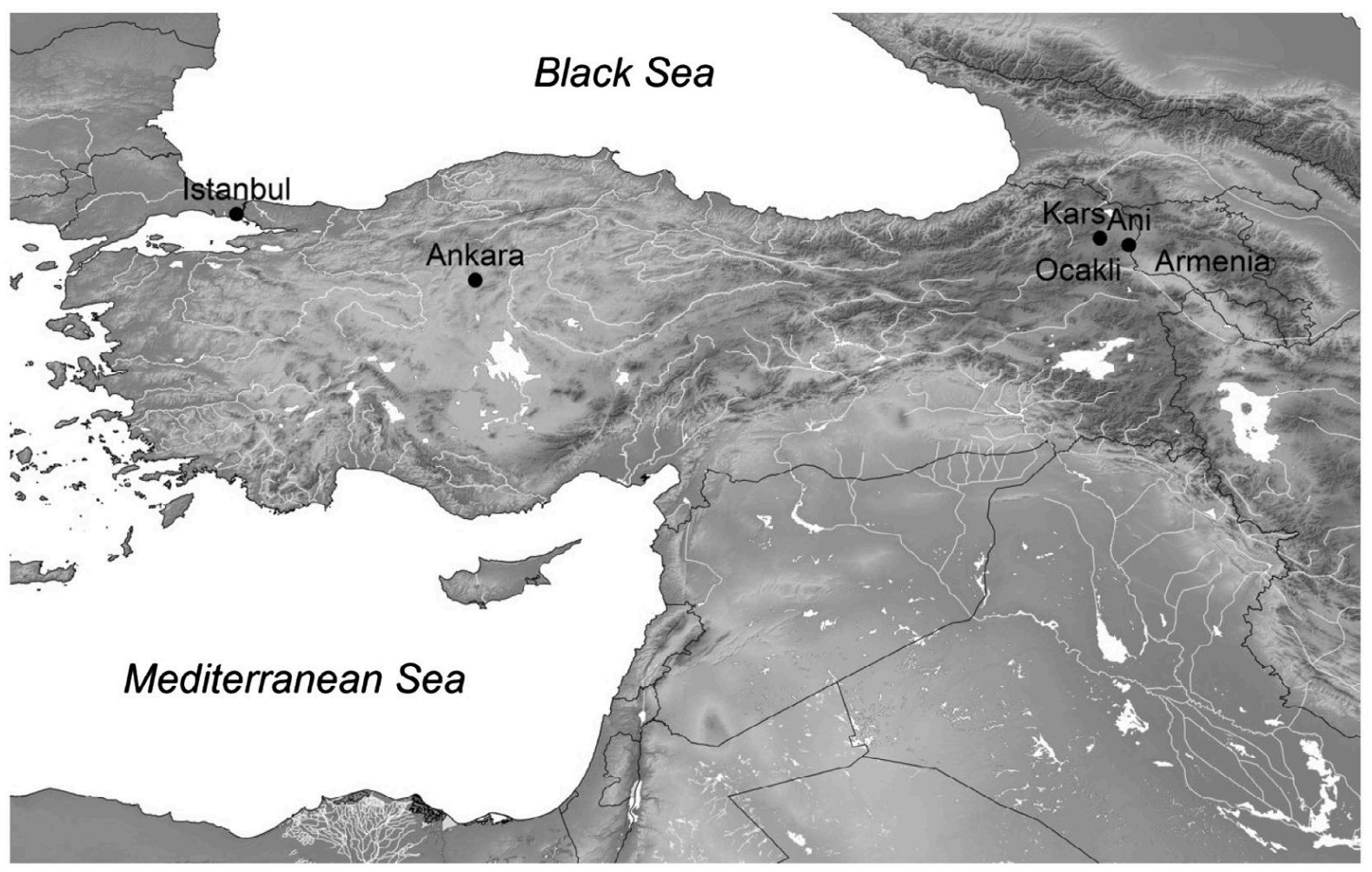

Figure 1. Location of Ani and Kars. Source: By the author.

Georgian archaeological remains and is especially famous for its Mediaeval Armenian architectural heritage, particularly for its churches (see Cowe 2001; Figures 3 and 4). The site was first significantly developed during the tenth century AD when it was the capital of the Armenian Kingdom and during the nineteenth and twentieth centuries the wider Ani province was quite multicultural, with groups including Armenians, Yezidis, Assyrians, and Malakans (Akçayöz et al. 2007). Today the population of the region is mostly a combination of Turkish and Kurdish people. However, the multicultural past can still be seen all around the province of Ani in the material culture around Ani and in the city of Kars (Figures 5 and 6).

The heritage site of Ani itself and the surrounding area were off limits until 2006 because it was highly contested territory between Turkey and Armenia, given that the border lies right next to the site Ani. However, more recently, the Turkish government has increased access and helped to restore some of the buildings at Ani in recent years and the site was inscribed as a World Heritage Site by UNESCO in 2015. Although the inscription to UNESCO will bring benefits to the heritage site in terms of long term preservation, this inscription can primarily be seen to have been brought with the aim of gaining more profit through tourism at Ani as part of neoliberal policies that market cultural heritage in Turkey.

Restoration is significant for preservation of heritage sites in that it can also create tourism and therefore has a great potential to bring profit particularly for local communities' economies. However, in the case of Ani, as most of local community members pointed out, they don't get any economic benefit from the heritage site. The site entrance fee goes to the ministry of Culture and Tourism; there is only one restaurant that is very occasionally open for tourists, who prefer to stay in the city and not the local area because there is nothing to keep them after visiting Ani. Moreover, locals don't have the capacity and qualifications to carry out tourism activities, and no capacity building training, e.g. tour guiding, hospitality, has been given to 
locals. Although the site gets large numbers of tourists and makes a profit because of the fees, the local village of Ocakl1 suffers from many infrastructure issues; there is a major issue with drinking water that remains unaddressed by the authorities (see Apaydin 2016c). I argue that the idea of restoration and preservation of heritage sites solely for tourism is an ethical issue. It jeopardises many heritage sites, encouraging state or other authorities to think that they should only invest and fund heritage sites that can bring more tourists and make more profit, and fails to recognise the leverage tourism can provide in terms of poverty reduction and investment in local communities.

The design of the site management plan demonstrates that the local people and stakeholders were excluded from the process (Apaydin 2016c). There has been no initiative taken to solve local problems and fulfil the expectations from the site. As most of the local members of the villagers point out, during the design of the management plan local members of the public were not even informed of how to participate in its development; demonstrably ordinary people were seemingly intentionally excluded from the decision-making process. Only relevant government institutions, local government, tourism agencies and the local village governor (muhtar) attended the meetings (Apaydin 2016c).

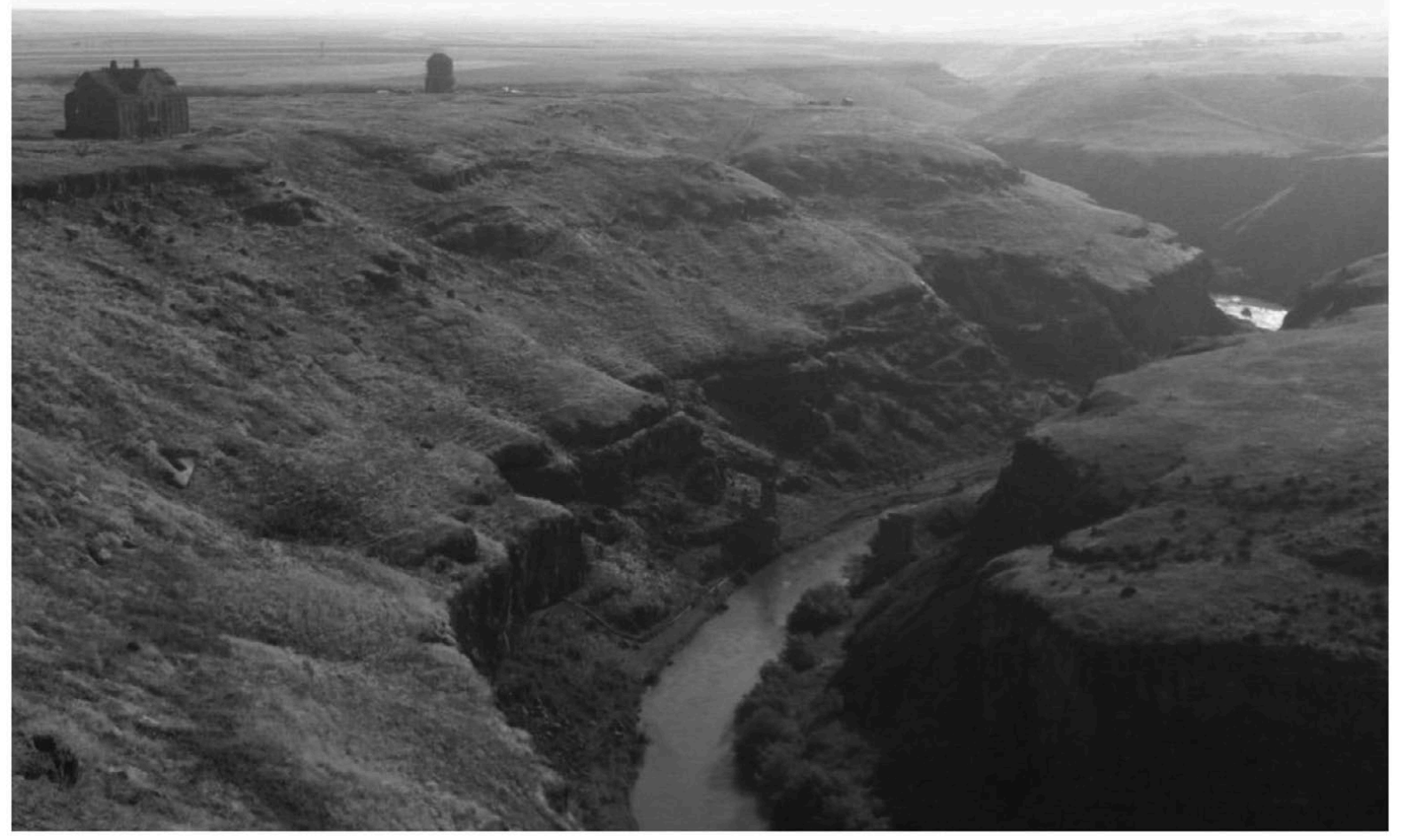

Figure 2. Arpacay River, a natural border between Turkey and Armenia. Ani on the left site, the right of the river is Armenia. Source: Cthe author. 


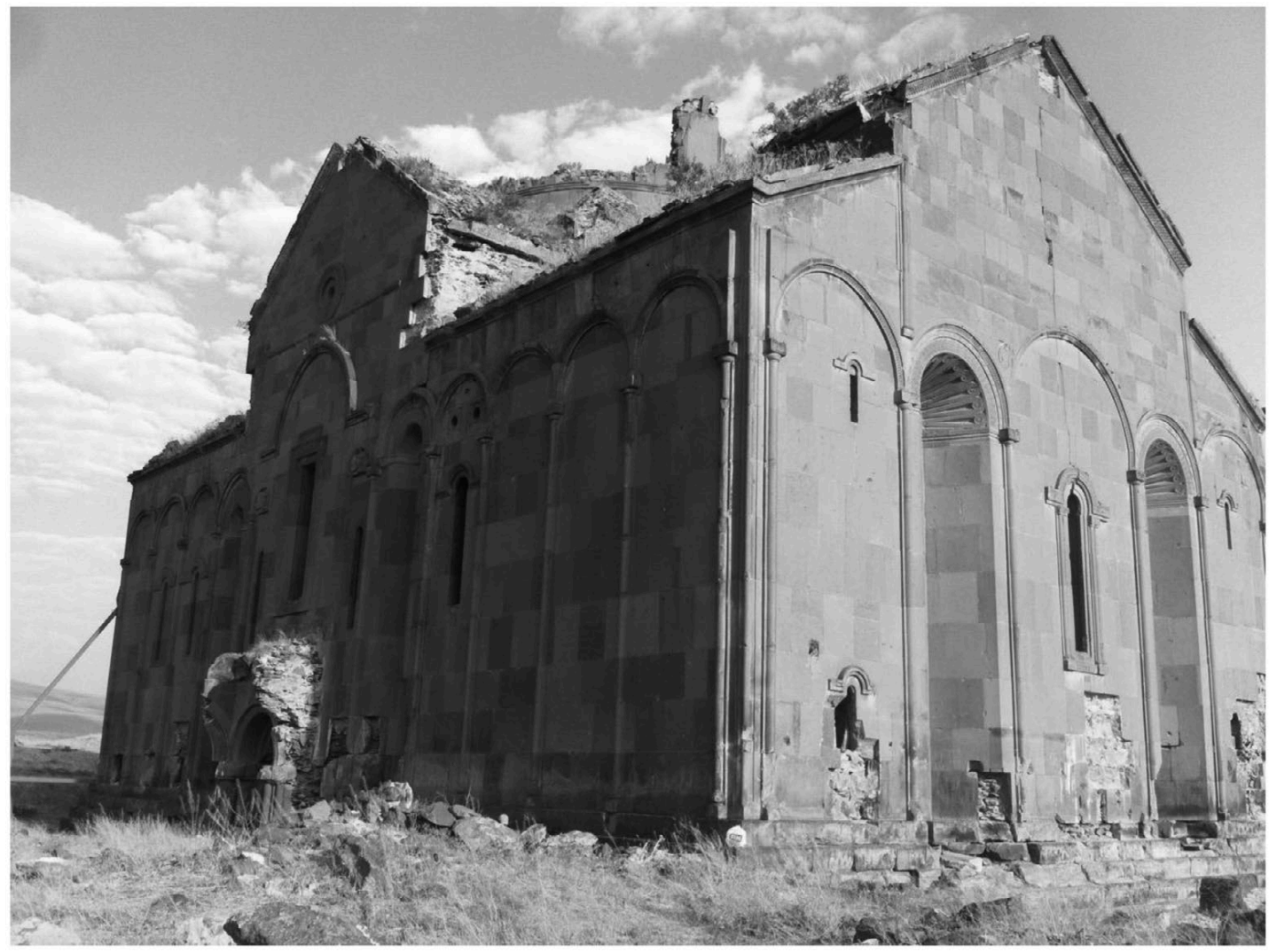

Figure 3. Famous Cathedral which was built during the Armenian Kingdom. Source: Cthe author.

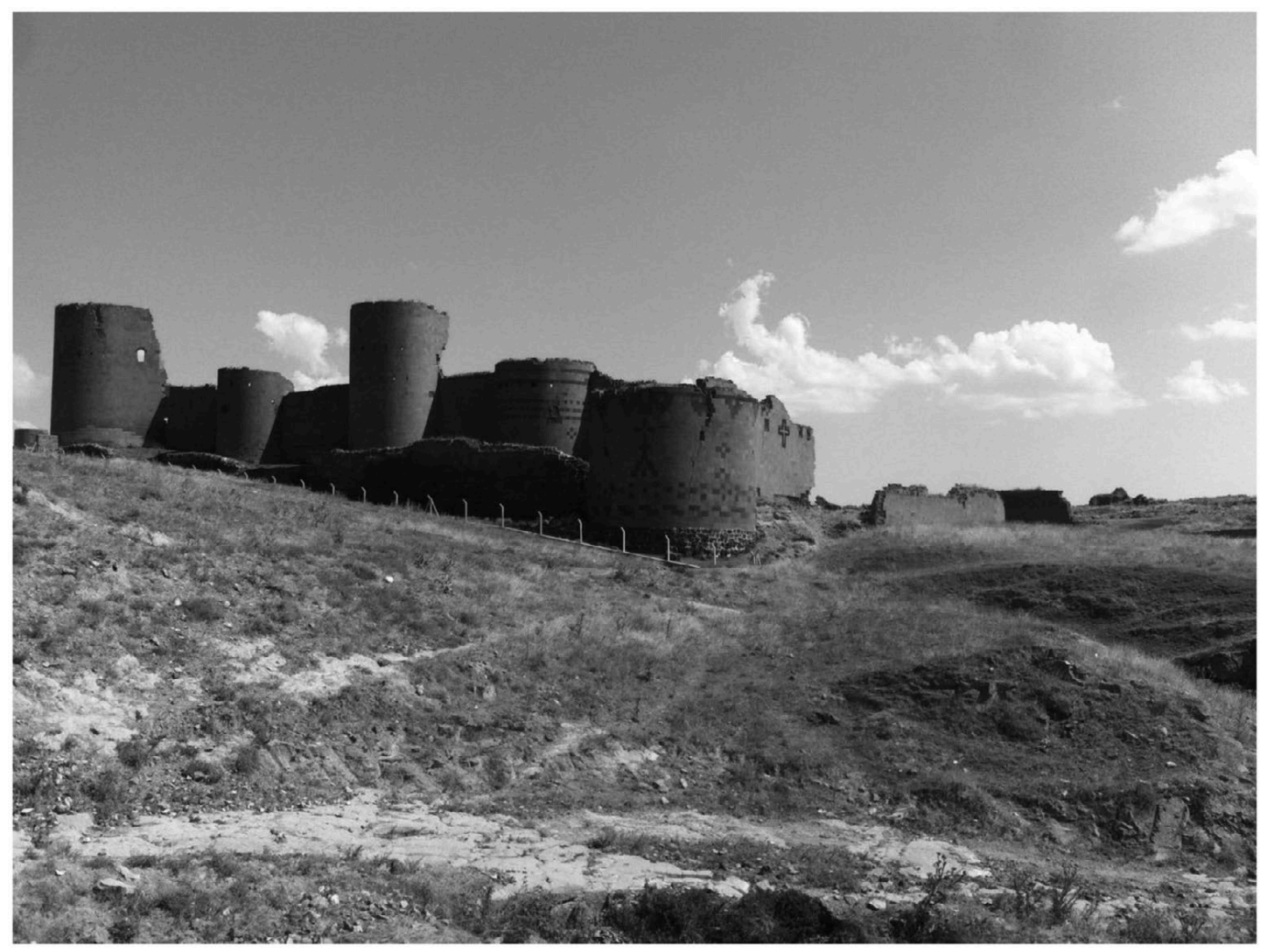

Figure 4. Ani city walls. Source: (C)the author. 


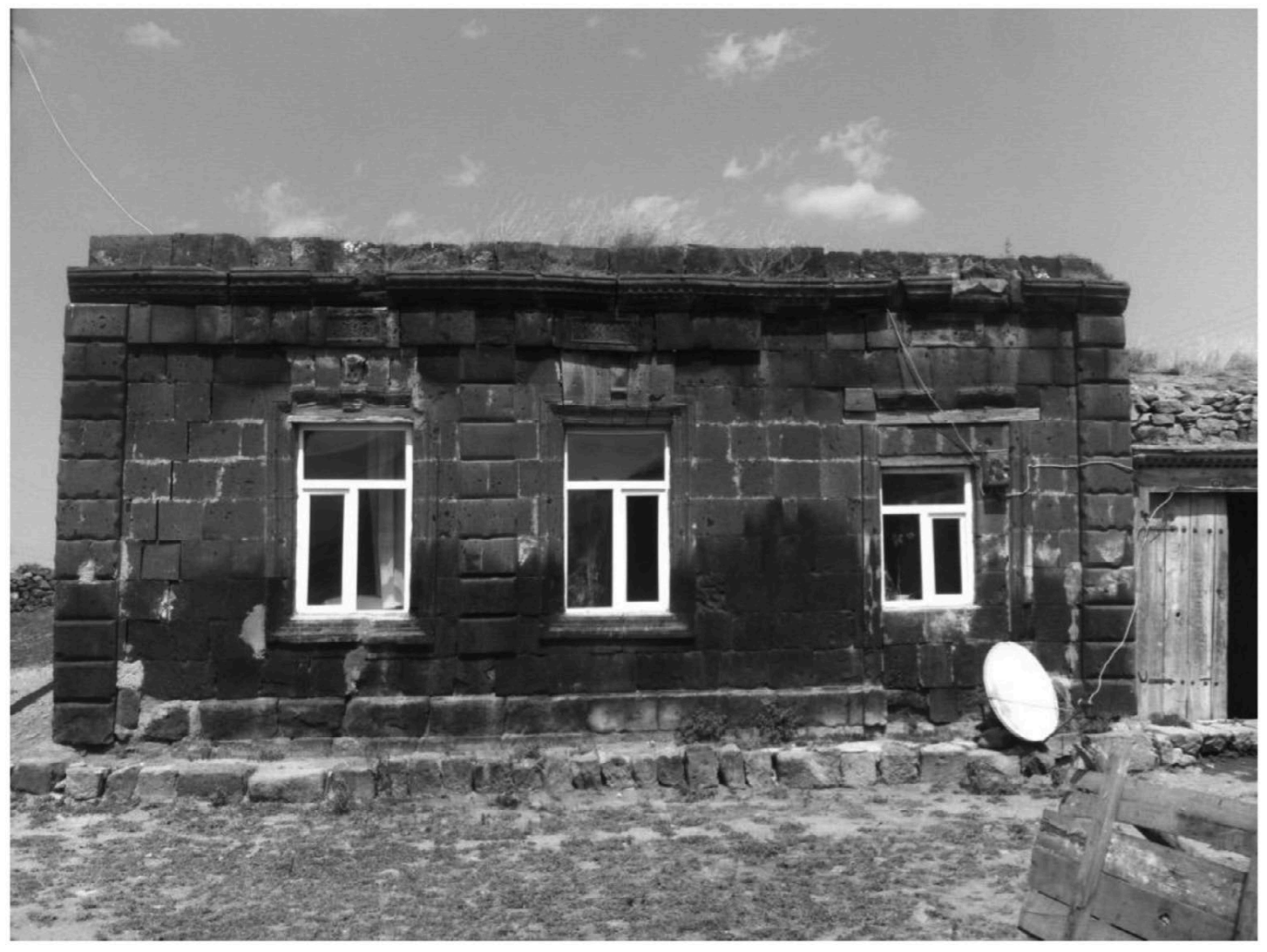

Figure 5. Traditional Armenians house with black stones in Ani province. Source: Cthe author.

The ethnographic approach The collection of data through ethnography that formed the basis for this article began with a pilot study in 2010, then continued until 2013 with six weeks each year, which comprised fieldwork in Ani, Kars, Istanbul and Ankara. My primary aims were to, firstly, expose how nationalist use of heritage resources and discourses was developed and used for identity making and national narratives, as well as their impact on the public. Secondly, I sought to identify the historical and present-day relationship of local people have developed with the heritage site and in particular to access older stories about these paces through the use of oral history. To this end, I conducted semi-structured in-depth interviews that let participants give their views and stories relating to the site, landscape and monuments. I also carried out participant observation to witness local peoples' daily lives and their relation to the heritage site and landscape.

The participant observations took place in the Ocakl1/Ani village both through direct observations as well as participating in daily life activities such as animal husbandry and farming. The interviews focused on the history of monuments of Ani and local history of the region. Since the multicultural ethnic structure of the region was purified from early twentieth century, I was only able to interview ethnically Turkish and Kurdish public members. Because of the conservative structure of the region the interview participants included only one woman; participants' ages varied between twenty-five and eighty. During the analyses of interviews', I used a Grounded Theory approach that allowed the exposition of interviewees' views on local heritage. Grounded theory is an approach that allow researchers to re-characterise and reidentify theory and research, and most importantly it is active during the analyses of the data, allowing the researchers to constantly compare, conceptualise, and interpret the data (see Glaser and Strauss 1967 for more detail). 


\section{Deconstructed and re-constructed heritage values in Ani}

I argue above that heritage is a process and therefore the meanings and values may change over a time. However, this process of changing meanings and values must come from the bottom up, as heritage should be truly accessible and democratic; it needs to be altered by people who have interlinkage with heritage. In contrast to this process, deconstructing the meanings and values at work in Ani demonstrates ideological discourses that are playing a large role in this process. For instance, Ani has unique standing monuments that have played a great role in the politics of Turkey in the past and today's as well as that of the Armenians in Armenia and the global diaspora (Watenpaugh 2014).

In the past, Ani was a strategic trading centre located on the Silk Road, thus, it was also a battleground between empires such as the Armenian Kingdom, Byzantine, Seljuk, and Georgian civilisations and was also subjected to the Mongol invasion. Although the majority of Ani's monumental heritage is from the Armenian Kingdom (see Cowe 2001) all these cultures left cultural traces, making Ani multicultural along with its Armenian past, and also important for the Georgian and Seljuk past. In contemporary politics, Ani is affiliated in the centre of national tension and illustrates in the way that how heritage create great tensions between groups.

The contestation of Ani between Turkey and Armenians goes back to first quarter of the twentieth century. Because of its many monuments representing the Armenian Christian past (see Cowe 2001), Ani used to be significant pilgrimage place for Armenians. These tours were promoted and guided by Armenian scholars such as Nicholas Marr, who was also first director of the excavations of Ani, and Toros Toramanian (see Watenpaugh 2014).

In contrast, Ani also represents a site of significant value for Turkish nationalists, as it marks the location of the arrival of ethnic Turks to Anatolia, when Sultan of Alparslan of Seljuk Empire in 1064 conquered the city. This is one of the reasons that Seljuk heritage is emphasised and promoted by Turkish nationalists. For example, in 2010, ultra-nationalists carried out a large rally in Ani to commemorate the victory in the eleventh century (BBC 2010), illustrating how cultural heritage can complicate and intensify the political tension between groups.

Most of the local ethnically Turkish population from and around Ani province do not recognise the existence of Armenians or their heritage in the region. The main reasons for this are the nationalist policies of the state, which is dominated by a Turkish and Islamic perspective (Zencirci 2014), and the impact of formal education that neglects the past and material culture of minorities, as well as using discriminative discourses against Armenians in the textbooks that portray them as an enemy (Bilmez et al. 2017) in order to keep the national narrative alive. As discussed above, this is partly to enable the Turkish state to claim ownership of these lands, arguing that this territory has always been Turkish; a phenomenon, including in the Armenian state (see Bilmez 2017), observed in many case studies from all around the world (see Kohl and Fawcett 1995; Meskell 1998); denying the links of a certain

identity group to the past. In this case, the hegemonic power of the state has tried to eliminate the material culture of the past of a certain group considered to be a threat to national unity. At the end of the Ottoman Empire, the period when nationalists took power, attempts at the destruction of Ani were seen due to the fact it contains significant monumental heritage, from the Armenian Kingdom (eleventh century), and was strongly linked to the modern identities of the Armenian minority population. 
One of the main figures in this episode was a leading general of the Turkish army, Kazım Kara Bekir. His reply to the Turkish ministry, who had demanded that Ani be demolished, is recorded:

There is no possibility of demolishing Ani. Its city walls are as big as Istanbul's city walls and it contains many churches ... if we demolish them it would increase the tension of the Armenian community in the region ... (Karabekir 1988, 924)

Even if the monumental heritage of Ani was not eliminated at that time, many assets of Armenian cultural heritage disappeared in the past because through neglect. For instance, according to the Armenian Patriarchate of Constantinople in 1914, 2549 religious sites were listed as under their control; a survey carried out in 1974 counted only 913 left (Bevan 2016, 78). City Kars, near Ani, also contained numerous houses of Armenian architectural style but many of them also vanished because of regeneration policies. According to the former officer of city municipality:

[...] under the plan of renovation of Kars, many Armenian houses ... almost $60 \%$ of the original houses were demolished by $2000 \ldots$ we legalized the protection plan for the heritage Kars ... we were able to save 310 of the Armenian houses however at least the same number were destroyed ... if the state wanted to protect them they could [...]

This anecdote demonstrates the current heritage policies in Turkey, which deem it necessary to demolish old houses and construct new ones which bring more profit, and subsequently many cities in Turkey have become construction sites (Apaydin 2016b), erasing the collective urban memory of complex heritage cities such as Istanbul. The account also shows that the demolished Armenian architecture, which had unique characteristics (Bevan 2016), could have been saved and protected. For instance, the town of Cumalıkızı in northwest Turkey, which is celebrated as the 'birthplace of the Ottoman Empire' is well protected and conserved, and inscribed as UNESCO World Heritage Site.3

The nationalist heritage policies, begun at the close of the Ottoman Empire, continued throughout the twentieth century. For instance, the original names of places that were not ethnically Turkish were switched to Turkish as a part of the process of purifying country from minority elements. The village that is located right next to Ani used to have same name as the heritage site but its name was changed to Ocakl1; likewise, the site information panels at Ani didn't mention Armenians at all until 2015. Similarly, the local museum, which has large collections from Ani and the Armenian period, neglects the Armenian past in the museum exhibition and instead emphasises other periods, in particular the Seljuk and Islamic eras. The reason for this is to preserve the state's national unity and not to break down the nationalist narrative, with museums serving as the symbols of collective identity and social memory in which a nation can create such a nationalist narrative; this is something Anderson (1983) describes as the 'imagined community'. Strong nationalist policies in every part of life have greatly affected the Turkish public perception and attitudes regarding local heritage. One of the residents in Kars expressed his views on Ani:

[...] Ani is important for us and it is my [our] past because the monuments and architecture, which contain much Turkish architecture, of the city, were built in the reign of sultan Alparslan4 who conquered Anatolia in 1071 and afterwards by Turks ... 
there is not such a past and history of Armenians in the region ... Ani and the region have always been Turkish and Islamic [...]

The interview clearly demonstrates that every individual interprets heritage and material culture through the lens of their political background, as Smith $(2006,2010,2012)$ has comprehensively demonstrated. However, I argue that political interpretation of past and heritage that forms the basis for this individual opinion is usually imposed by the elites. The general public is usually told what to think and how to interpret heritage. The local quoted above did not recognise the existence of Armenians or their heritage and demonstrates heritage knowledge imposed during his education at school (see Bilmez et al. 2017), claiming the all monuments and architecture of Ani were built during the Seljuk Empire and neglecting the 'other' pasts such as Armenian or Georgian. This highly selective knowledge

regarding Armenians and their heritage is quite common in the region. A villager of the Ani/Ocakli village, for example, offers proof of the nationalist use of past that permeates education and daily life:

[...] What I [we] know about the past of this region is that it was always Turkish, only the Russians occupied it for several years in the past but we [Turks] took our lands back again $[\ldots]$

The account of this villager also illustrates how heritage discourse imposed by Turkish elites has impacted on local people and their interpretation of history and heritage. The existence of the Armenian past in the region is in fact very well-known because of the remaining monumental architectural heritage such as houses and churches that contain inscriptions in Armenian and Christian icons. However, the same participant, from the Ani village, still argues against this:

[...] The Armenian inscriptions were made during the Russian invasion ... Armenians came here to take over our lands together with the Russians during the war [...]

Such commentary also reveals how values and meanings of heritage can be re-constructed by imposing a nationalist heritage discourse; these accounts strongly neglect the existence of Armenians and their past and heritage in Ani and the region. In addition, the villager reinterprets Ani and re-values Ani in parallel to official heritage discourse. The region of Ani is also the official border with the state of Armenia, a country that has had a long history of conflict with Turkey and therefore also represents the borderline of the state identity (Donnan and Wilson 1999); for this reason the Turkish state and nationalists have attached extra importance to defining this region and the site of Ani. While neglecting Ani's Armenian past was useful for developing national narratives by Turkish state in the past, we can also look at how the site was used to keep an alternative collective identity alive; what it means and symbolises and how it is used by Armenians.

\section{Uses, values and meaning of Ani for Armenians}

Developing myths and imaginations, glorifying history and making connections with older civilisations to claim ownership rights of territory are always core assets for nationalism, national narratives and identity making (Kohl and Fawcett 1995). Armenian nationalism is no exception (see Rutland 1994). The main difference in Armenian nationalism is bound up two different forms: first, nationalism that is based in Armenia and has formed around Armenian church (Apostolic church) and the second 'diaspora nationalism' as many Armenians live in different parts of the world (Guroian 1994). Both parties give great importance to past and 
heritage of Armenians. For instance, a recent substantial study, conducted by Turkish and Armenian scholars and funded by the EU, considering the 'history education in schools in Turkey and Armenia' (Bilmez et al. 2017) and revealed the similarity of uses of the past and heritage materials in developing and reconstructing values and meanings for both sides. In the history education of Armenia, the history of the Armenian Apostolic church is compulsory and takes a prominent place; the church also takes part in designing curricula and textbooks even though Armenia has, officially, a secular education system. The textbooks also use discriminative language; for instance, Turks are usually presented in the narratives as the enemy. The textbooks make narratives that glorify Armenian history through text, images and maps, and emphasise the ideal that 'Armenians are unique, always homogenous, and proud of an ancient heritage' (Bilmez et al. 2017, 51).

Ani has been given great attention and importance by the Republic of Armenia, which considers it one of its key asset for national history (Watenpaugh 2014). Ani's great cathedral (see Figure 6), which was built in the eleventh century, is very significant for the Apostolic church, as it is one of the earliest cathedrals. Ani as a heritage site has also been used as a tool by nationalist Armenians, promoted through right wing discourses that neglect the multicultural past of Ani and always emphasise how significant it is for Armenian national identity. For instance, to commemorate the one-thousand-and-fiftieth anniversary of Ani, many exhibitions and events were carried out in 2011 to emphasise its importance for Armenian culture, past and identity. For example, most prominently with the exhibition 'Ani: Capital of Armenia - 10505' which was exhibited at the History Museum of Armenia in Yerevan and subsequently travelled to many other countries, and included collections of photography and even a model city of Ani.

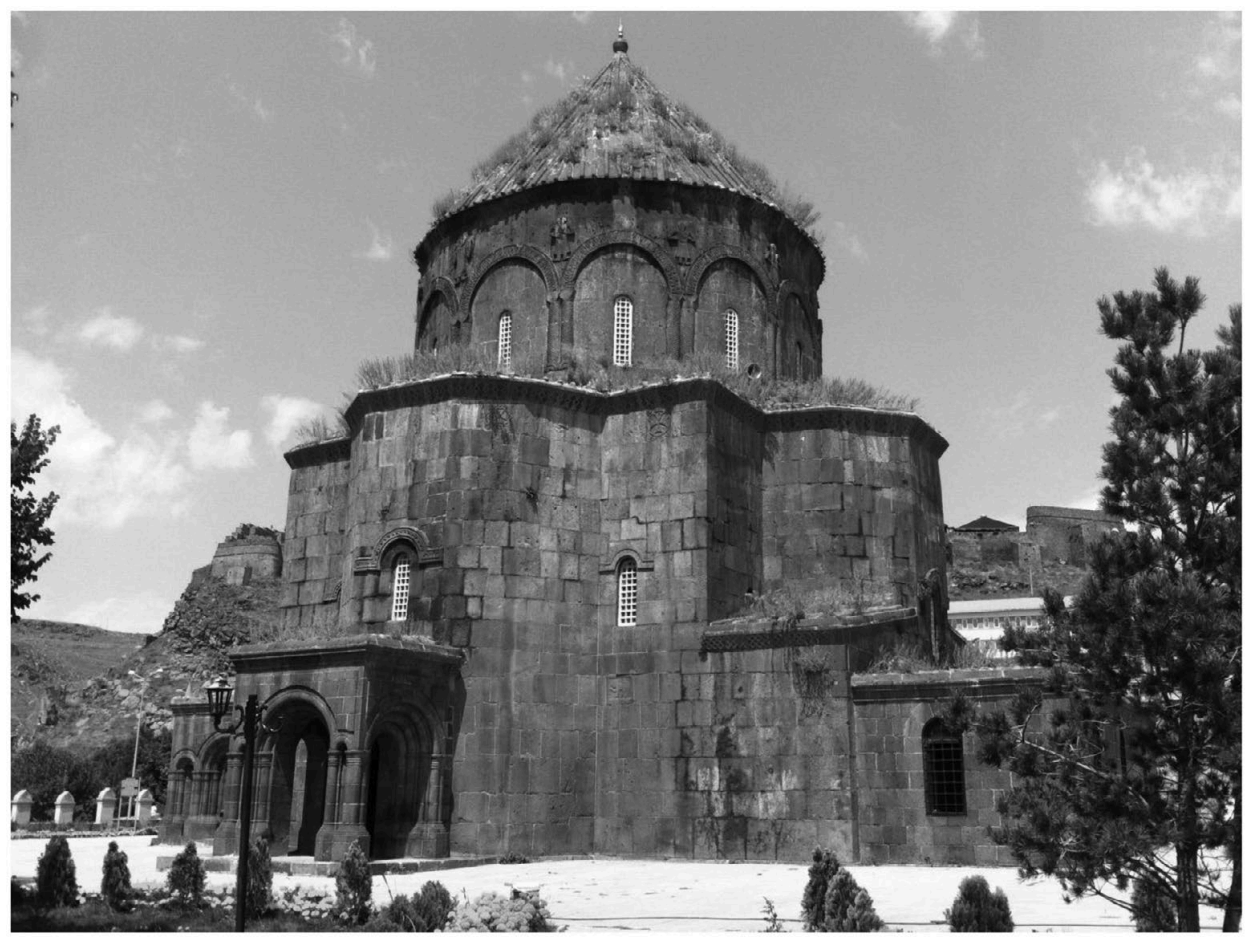

Figure 6. Apostles Church (Kumbet mosque) in Kars. Source: Cthe author.

The research carried out for this paper was limited in ability to investigate heritage perception in Armenia and diaspora. However, use of heritage and past materials and history for national 
narratives in education and other forms of public events are greatly impacting public's perception of Armenians as well, as in the case of Turks in Turkey. Ani receives 50,000 tourists a year, and many of the foreign tourists are from Armenian diaspora. The main reason they visit would appear to be because, in one Armenian visitor's words: 'the site is still storing memories, and important for Armenian collective identity'. Certainly, this is also related to maintaining their understanding of the past as Ani provides evidence of this, which correlates to Gellner's (1983) argument that diaspora nationalism is based on thread of assimilation and elimination. For instance, one visitor, who lives in France but whose grandparents were originally from eastern Turkey explains the importance:

[...] although I was born and grew up in France ... the real home is here for me [...]

Though there are no Armenians left in the region, I managed to talk to some members of the Armenian community in Istanbul. While Armenians who live in Turkey are less affected by Armenian nationalism in Armenia or diaspora nationalism, most of them also pointed out how material culture of the past was symbolically important for their collective identity. They articulated feelings about use of discriminative languages and making them 'other'; how Ani expresses their vanishing heritage, as well as how it has a potential to open up dialogue and build a sustainable future by recognising its multicultural past. One described how:

[...] although we are originally from these lands we have been made 'other' and our cultural heritage in many parts of the Turkey has been erased [...]

The view of another person of Armenian-origin who lives in Istanbul but was originally from the Ani region, points out:

[...] Ani is important for us, it represents our culture and our existence in these lands ... however, as long as it is protected and access is possible, I don't mind who owns it $\ldots$ it had many civilizations such as e.g. Armenians and Turks $[\ldots]$

Although cultural heritage is highly political and discourses are often developed by hegemonic powers or certain elites, it has also meaning and value for local communities in their daily lives. Therefore, the question remains: what is the meaning and value of Ani and heritage sites in daily practice for local people who live nearby and have daily engagements with the heritage site and landscape?

\section{Sense of place and heritage values in Ani}

Living in and next to a heritage site and its landscape for almost a hundred years has led ethnically Turkish locals to form a personal and communal relationship with Ani and has resulted in a variety of ascribed values and meanings (see Ashworth and Graham 2005; Waterton 2005; Smith 2006; Smith and Waterton 2009) and memories with the site and its landscape separate from nationalist discourses and narratives that are developed by elites, as discussed above. For example, local residents around the site point out that Ani/Ocakli villagers used to live in the caves of the Ani heritage site until they were forced to move to the modern village in 1950's but they still see the original site as important in their daily lives. Although the buildings and monuments of the heritage site are mostly Armenian and in spite of the fact that most of the local people interviewed for this research have reservations about Armenian heritage imposed by state and nationalist propaganda, the heritage site with its buildings and 
monuments became part of their lives to which they ascribed meanings and values over time, and these meanings and values are opposed to a state-led authorised heritage discourse.

One of the older members of the village, who used to live in the caves of Ani, narrated the local populations' relationship to and the meanings of Ani and the landscape while showing me the cave where he used to live, but which is now used as a barn. He showed the galleries of the cave where he used to sleep, the gallery they used for baking, and the gallery used as a living room with his parents. He comments:

[...] we used to live in this cave for long time. I remember that we used to bake bread in this oven [oven is still in the gallery] ... the cave was keeping us very warm during winter and it made very cool during the summer $[\ldots]$

[...] until 1950's, we used to live in the caves of Ani ... it was our home [...]

These commentaries expose how memory has been layered over this place and how meaning of such places can be different at a local level as well as it highlights the 'sense of place' for him. Although memory has always been embedded in the contested political relationship between past and present (Hodgkin and Radstone 2003) and to speak about particularly regarding concepts of the 'contested past', memory is also developed through an individual relationship with the heritage site. It is still through the processes of daily life that the meaning of these memories can be changed; the cave gallery is used as a barn today and has now been loaded with different meanings and developed different memories for future resources.

This 'sense of place' is without doubt developed over time, and its value is formed accordingly. However, one of the periods of our lifetimes is of more importance in this than any other: our childhood. Our memories from this time shape our personalities and views (Smith 2013, 115). Almost every single villager from Ani village has a childhood memory associated with Ani and its buildings, as many of the villagers describe:

[...] every monument and building of Ani is important for me, as we used to play and had a picnic with friends and family long ago [...]

[...] it [Ani heritage site] encompasses all my childhood memories. Since early age, my friends and I used to play and spend time in Ani [...]

Currently, villagers cannot access or use the site monuments and its landscape as they did in the past because of the new heritage management plan for the site, developed during the process of inscription of the site as a UNESCO World Heritage Site (see Figure 7 for the borders of the heritage site and village). The anecdotes of the villagers discussed above demonstrate that the design of the management plan was very top-down and the views and expectations of the locals weren't taken into account. The site and its landscape is now fenced off, guarded by security, and entrance is only allowed for a fee. The management plan has acted as a tool to change the relationship of locals with their heritage as well as reconstructing the 'sense of place' of the local community that had developed here over a long time-period. 


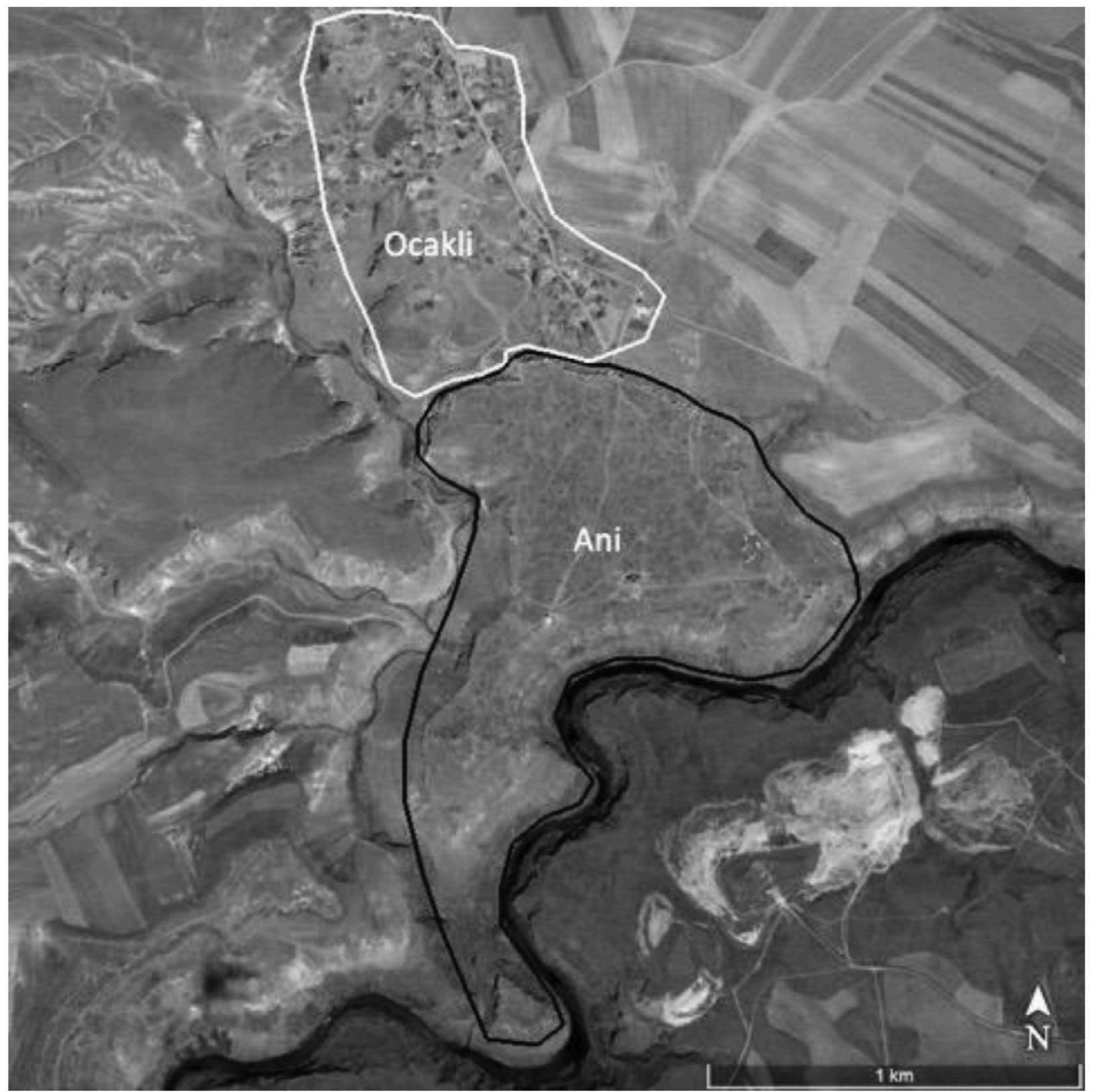

Figure 7. Google Earth View of UNESCO World Heritage Site Ani and Ocakl1 village. Source: Map data: Google earth. 2017 Digital Globe

The economy of the village and the region as a whole is dependent on animal husbandry and farming. The villagers' economical condition is quite low and beyond these poorly-paid industries there are few options for other employment. The site of Ani occupies quite a large area in the region, and the villagers used to graze their animals on it because the other side of Ani was (and remains) Armenian territory, as well due to the fact there are nearby off limits military zones sealed off by both countries. The participants in this research that were also residents of Ani village point out the economic impact of the heritagezation of Ani:

[...] Most of villagers' survival depends on animal husbandry and Ani has been our most productive place for grazing (with the protection law this has been restricted) [...]

Not just one but almost all of the villagers emphasised the importance of animal husbandry and the difficulties they experienced after the site was fenced off and grazing was banned. This demonstrates the economic meaning and value of Ani for local members of the public in the 
face of official meanings and values imposed by the state. Although the heritage perception of local members of the public has been shaped by the official ideology, and they recognise official meanings and values of the site, in daily life the official ideology loses its importance. During my participant observations, most of the locals pointed out issues including water problems in the village, infrastructure, poor quality health and education services, limited grazing areas, and most importantly, the economic problems that they have been having. This latter issue was caused by political disputes between Turkey and Armenia with the border between both countries having been closed and trade stopped, which had previously made a great contribution to the local economy. That local people have different priorities in this impoverished region than the political agendas which are imposed by elite politicians is evident through my interviews.

The site and landscape also present an example of 'a sense of place' can be developed and how meaning and value can be significantly different at a local and individual level than at the national political level. It is significant to acknowledge this fact for the protection and preservation of these kind of heritage sites as local people are the natural guardians of cultural heritage sites (Pearson and Sullivan 1995). However, most cultural heritage management plans, including those meeting UNESCO world heritage site inscription criteria, don't acknowledge this fact and still impose values and meanings on heritage that were originally formed through 'western elites' (Smith 2006, 11). By contrast, as emphasised by Smith (2006) and Waterton (2005), heritage and landscape have a central meaning for local communities and people who have everyday engagement with heritage may have a very different experience of and perspective on heritage sites and landscapes; different values are ascribed to heritage by local people who engage with it in daily life, as part of ongoing long-term processes of meaning making.

\section{Conclusion}

This paper has attempted to present how cultural heritage and heritage landscapes can have varied importance, meanings, values, and uses for different stakeholders and groups, each of whom have different relationships with and agendas for the material culture of the past. It is certainly true that heritage and its management as practiced today is often used to reassert the legitimacy and reinforce the power of hegemonic entities. However, as the case of Ani demonstrate, while heritage can be used for political purposes for identity making and nationalist discourses - it can also have a different meanings and values in daily life. Although evidence of 'hegemonic' or 'authorized' heritage discourses can be seen to operate fairly universally, value and meaning of heritage can only be different at the local level because of the daily relationship of local people and the use of such heritage resources in their daily lives.

Every individual and every group may have varied social and economic backgrounds, and thus their needs will vary in terms of how heritage can play a role as a resource for local populations. For example, Smith (2006) clearly demonstrates the difference between authorised heritage discourse and the local community's sense of heritage in Castleford in the United Kingdom. The town of Castleford represent significant history for industrial heritage as it was one of the significant mining town and Roman period, which is often regarded as quite significant in British national identity making and used as part of authorised heritage discourse (Smith 2006). In contrast, she emphasises that when heritage is used primarily to play a part of politics and national narratives, alternative uses of heritage and memories that developed between place and locals as a result of daily relationships, are often neglected. Dines $(2012,2016)$ relatedly demonstrates how local communities' use of public space can be oppose to top-down heritage 
discourses in Naples, Italy. Zhang and Wu (2016) explores the different meaning and understanding of a Chinese village's heritage. Similarly, Ani as a heritage site, built environment, and landscape embodies meaning and value in opposition to nationalist positions and 'authorized heritage discourse' but also highlights the inherent contest and contradictory nature of heritage value, particularly where historic ownership of sites is contested.

At the beginning of this paper, I argued that heritage is a process and its meaning and value vary with different groups, and this is part of the natural development of heritage process. On one hand, the local people of Ani demonstrate how this change is possible through developing a sensory and daily relationship with the heritage site and its landscape, away from political tension and nationalist agendas. On the other hand, we can see how the symbolic importance and multicultural past of Ani can be revived and should be considered as a positive asset to build sustainable future between groups in conflict. Although this is a difficult thing to achieve it should be encouraged if possible and that in other regions the likes of Heritage management plans must be used not fence off heritage but embrace its complexity and diverse values. Such sites with this varied value need to be barriers but means of promoting intercultural cooperation and building trust between communities.

\section{Notes}

1. Hattusa is a capital of Hittite Empire that is located in the central Northwest of Turkey.

2. http://whc.unesco.org/en/tentativelists/6035/.

3. see http://whc.unesco.org/en/list/1452.

4. The Sultan of the Seljuk Empire, AD 1029-1072.

5.https://historymuseum.am/en/exhibitions/past_exhibitions/Ani-Capital-Of-Armenia1050 .

\section{Acknowledgements}

I wish to thank community members for taking part in this study. I would also like to thank to reviewers of this paper and the editor of International Journal of Heritage Studies for their great, helpful and critical comments. 


\section{References}

Akcam, T. 2004. From Empire to Republic: Turkish Nationalism and the Armenian Genocide. London: Zed books.

Akçayöz, V., T. Çakaş, Y. Öztürkkan, S. Yazıcı, and O. Yurdalan. 2007. Kars Kent Rehberi. Istanbul: Kars Kent Konseyi.

Akdar, A. 2000. Varlık Vergisi Ve Türkleştirme Politikaları. Istanbul: Iletişim Yayınları.

Anderson, B. 1983. Imagined Communities: Reflections on the Origin and Spread of Nationalism. London: Verso.

Apaydin, V. 2016a. "Development and Re-configuration of Heritage Perception: History Textbooks and Curriculum in Turkey." AP Online Public Archaeology Journal 7: 27-50.

Apaydin, V. 2016b. "The Challenge of Neoliberalism and Archaeological Heritage in Turkey: Protection or Destruction?" In Archaeology and Neoliberalism, edited by P. Aparicio-Resco, 341-352. Madrid: JAS Arqueología Editorial.

Apaydin, V. 2016c. "Economic Rights, Heritage Sites and Communities: Sustainability and Protection.” Complutum 27 (2): 369-384. doi:10.5209/CMPL.54751.

Ashworth, G. J., and B. Graham, eds. 2005. Senses of Place: Senses of Time. Aldershot: Ashgate.

Ashworth, G. J., Brian Graham, and J. E. Tunbridge. 2007. Pluralising Pasts. Heritage, Identity and Place in Multicultural Societies. London: Pluto Press.

Atakuman, C. 2008. "Cradle or Crucible: Anatolia and Archaeology in the Early Years of the Turkish Republic (1923- 1938).” Journal of Social Archaeology 8: 214-235.

Atkinson, D. 2007. "Kitsch Geographies and the Everyday Spaces of Social Memory." Environment and Planning A 39: 521-540.

Aydın, S., and Y. Taşkın. 2014. 1960'dan Günümüze Türkiye Tarihi. Istanbul: Iletişim Yayınları.

Baraldi, B. S., D. Shoup, and L. Zan. 2013. "Understanding Cultural Heritage in Turkey: Institutional Context and Organizational Issues." International Journal of Heritage Studies 19 (7): 28-748.

BBC 2010. "Turkish nationalists rally in Armenian holy site at Ani". BBC October 1. Accessed September 1 2017. http:// www.bbc.co.uk/news/world-europe-11454014.

Bevan, R. 2016. Destruction of Memory: Architecture at War. London: Reaktion Books Ltd. 
Bilmez, B., K. Cayir, O. Caykent, P. Gamaghelyan, M. Karapetyan, and P. Sayan. 2017. History Education in Schools in Turkey and Armenia. a Critique and Alternatives. Istanbul and Yerevan: History Foundation (Tarih Vakfi) and Imagine Center for Conflict Transformation.

Buğra, A., and Savaşkan, O. 2014. New capitalism in Turkey. The relationship between politics, religion and business. Cheltenham: Edward Elgar

Byrne, D. 2008. "Heritage as Social Action.” In Heritage Reader, edited by G. Fairclough, R. Harrison, J. Jameson, and J. Schofield, 149-173. New York: Routledge.

Convery, I., G. Corsane, and W. Davis, eds. 2012. Making Sense of Place. Multidisciplinary Perspectives. Woodbridge: Boydell \& Brewer.

Cowe, P. S., ed. 2001. Ani. World Architectural Heritage of a Medieval Armenian Capital. University of Pennsylvania Armenian Text and Studies; 16. Peeters, Leuven, Sterling, Virginia.

Crooke, E. 2008. Museums and Community: Ideas, Issues and Challenges. New York: Routledge.

Davis, P. 1999. Ecomuseums: A Sense of Place. London: Leicester University Press.

Dicks, B. 2000. Heritage, Place and Community. Cardiff: University of Wales Press

Dines, N. 2012. Tuff City: Urban Change and Contested Space in Central Naples. New York: Berghahn.

Dines, N. 2016. "Ethnographic Reflections on 'Oppositional Heritage Discourse'in Two Postearthquake Italian Cities.” International Journal of Heritage Studies 22 (2): 102-116. doi:10.1080/13527258.2015.1053401.

Donnan, H., and T. M. Wilson. 1999. Borders: Frontiers of Identity, Nation and State. Oxford: Berg.

Ersanl1, B. 2003. Iktidar ve Tarih. Türkiye’de “Resmi Tarih” Tezinin Oluşumu (1929-1937). Istanbul: Iletişim Yayınları.

Gellner, E. 1983. Nation and Nationalism. Oxford: Blackwell.

Glaser, B. G., and A. L. Strauss. 1967. The Discovery of Grounded Theory: Strategies for Qualitative Research. Hawthorne, NY: Aldine de Gruyter.

Graham, B., G. J. Ashworth, and J. E. Tunbridge. 2000. A Geography of Heritage. London: Arnold.

Guler - Biyikli, S., and C. Aslan. 2013. "A Review of Cultural Heritage Education in Turkish Schools (1962-2011).” Public Archaeology 12 (4): 255-270.

Guroian, V. 1994. "Religion and Armenian National Identity: Nationalism Old and New." Occasional Papers on Religion in Eastern Europe, 14 (2), Article 3. 
Harrison, R. 2013. Heritage. Critical Approaches. London: Routledge.

Harvey, D. C. 2001. "Heritage Pasts and Heritage Presents: Temporality, Meaning and the Scope of Heritages Studies." International Journal of Heritage Studies 7 (4): 319-338.

Hawke, S. 2012. "Heritage and Sense of Place: Amplifying Local Voice and Co-constructing Meaning." In Making Sense of Place Multidisciplinary Perspectives, edited by I. Convery, G. Corsane, and P. Davis, 235-248. Woodbridge: Boydell \& Brewer.

History Museum of Armenia. 'Ani: Capital of Armenia - 1050'. Accessed August 3, 2017. https://historymuseum.am/en/exhibitions/past_exhibitions/Ani-Capital-Of-Armenia-1050

Hodgkin, K., and S. Radstone. 2003. Contested Past. The Politics of Memory. London: Routledge.

Holtorf, C. 2015. “Averting Loss Aversion in Cultural Heritage." International Journal of Heritage Studies 21 (4): 405-421. doi:10.1080/13527258.2014.938766.

Karabekir, K. 1988. Istiklal Harbimiz. Istanbul: Merk Yayıncılık.

Kohl, P. L., and C. P. Fawcett, eds. 1995. Nationalism, Politics, and the Practice of Archaeology. Cambridge: Cambridge University Press

Lowenthal, D. 1996. Possessed by the Past. New York: Free Press.

Lowenthal, D. 2008. The Heritage Crusade and the Spoils of History. Cambridge: Cambridge University Press.

Meskell, L., ed. 1998. Archaeology under Fire: Nationalism, Politics and Heritage in the Eastern Mediterranean and Middle East. London: Routledge.

Pearson, M., and Sullivan, S. 1995. Looking After Heritage Places. Carlton, Victoria: Melbourne University Press.

Rutland, P. 1994. "Democracy and Nationalism in Armenia.” Europe-Asia Studies 46 (5): 839861.

Schofield, J., and F. Szymanski, eds. 2011. Local Heritage, Global Context; Cultural Perspective on a Sense of Place. Farnham: Ashgate.

Shoup, D. 2006. "Archaeology Build a Dam? Sites and Politics in Turkey's Southeast Anatolia Project." Journal of Mediterranean Archaeology 19 (2): 231-258.

Silverman, H., ed. 2011. Contested Cultural Heritage. Religion, Nationalism, Erasure, and Exclusion in a Global World. New York: Springer.

Smith, L. 2006. Uses of Heritage. London: Routledge. 
Smith, L. 2010. "Ethics or Social Justice? Heritage and the Politics of Recognition." Australian Aboriginal Studies 2: 60-68.

Smith, L. 2012. "The Cultural 'Work' of Tourism." In The Cultural Moment of Tourism, edited by L. Smith, E. Waterton, and S. Watson, 210-234. London: Routledge.

Smith, L. 2013. "Taking the Children. Children, Childhood and Heritage Making." In Children, Childhood and Cultural Heritage, edited by K. Darian-Smith and C. Pascoe, 107-125. London: Routledge.

Smith, L., and N. Akagawa, eds. 2009. Intangible Heritage. Abingdon: Routledge.

Smith, L., and E. Waterton. 2009. "The Envy of the World? Intangible Heritage in England." In Intangible Heritage, edited by L. Smith and N. Akagawa, 289-302. Abingdon: Routledge.

Tunbridge, J. E., and G. J. Ashworth. 1995. Dissonant Heritage: The Management of the past as a Resource in Conflict. Chichester: Wiley.

Tureli, I. 2014. "Heritagisation of the 'Ottoman/Turkish House' in the 1970s: Istanbul-Based Actors, Associations and Their Networks.” European Journal of Turkish Studies 19: 1-32.

Vale, L. 2008. Architecture, Power and National Identity. Abingdon: Routledge.

Watenpaugh, Z. H. 2014. "Preserving the Medieval City of Ani. Cultural Heritage between Contest and Reconciliation." Journal of the Society of Architectural Historians 73 (4): 528555.

Waterton, E. 2005. "Whose Sense of Place? Reconciling Archaeological Perspectives with Community Values: Cultural Landscapes in England." International Journal of Heritage Studies 11 (4): 309-325. doi:10.1080/13527250500235591.

Zencirci, G. 2014. "Civil Society's History: New Constructions of Ottoman Heritage by the Justice and Development Party in Turkey." European Journal of Turkish Studies 19: 1-20

Zhang, Y., and Z. Wu. 2016. "The Reproduction of Heritage in a Chinese Village: Whose Heritage, Whose Pasts?" International Journal of Heritage Studies 22 (3): 228-241. doi:10.1080/13527258.2015.1114505. 